\section{EFFECT OF MANIHOT ESCULENTA AQUEOUS EXTRACT AND THERAPEUTIC ULTRASOUND IN ACCELERATING THE WOUNd Healing Process IN Vitro}

\author{
Ulfah Anwar, Siti Pauliena Mohd Bohari* \\ Faculty of Biosciences and Medical Engineering, Universiti Teknologi \\ Malaysia, 81310 UTM Johor Bahru, Johor, Malaysia
}

Article history

Received

9 September 2018

Received in revised form

18 March 2019

Accepted

14 May 2019

Published online

25 June 2019

*Corresponding author pauliena@fbb.utm.my

\section{Graphical abstract}

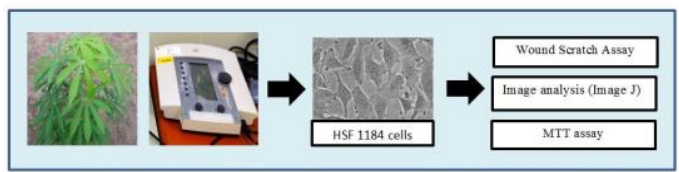

\begin{abstract}
The aim of this research is to investigate the wound healing process in in vitro by combining the Manihot esculenta aqueous extract and therapeutic ultrasound. Firstly, the optimization seeding densities of HSF cell 1184 in six-well plate, and then followed by the scratch assay experiment. The scratched that made was treated with the remedial treatments (Manihot esculenta aqueous extract only; ascorbic acid+ therapeutic ultrasound; Manihot esculenta aqueous extract+ ascorbic acid; Manihot esculenta aqueous extract+ therapeutic ultrasound and also the combination of these three materials). The rate of wound closure was observed and analysed at a time interval of $0,2,4,6,8,10$ and $24 \mathrm{~h}$ by using image $\mathrm{J}$ software. Then, the cells viability were analysed using the MTT assay. The result showed that Manihot esculenta aqueous extract coupled with specific dose therapeutic ultrasound represents a significantly high rate of wound closure at $96.10 \%$ with the cell numbers at $5.44 \times 10^{5} \mathrm{cells} / \mathrm{mL}$ when compared to the other combination therapy. The finding of this study revealed that Manihot esculenta aqueous extract $200 \mu \mathrm{g} / \mathrm{mL}$ and the therapeutic ultrasound specific dose ( $3 \mathrm{MHz}, 300 \mathrm{mWatt} / \mathrm{cm}^{2}, 50 \%$ in $5 \mathrm{~min}$ ) have the potential in accelerating wound healing process of cells in in vitro.
\end{abstract}

Keywords: Wound healing, Manihot esculenta, therapeutic ultrasound, scratch assay, MTT assay

\begin{abstract}
Abstrak
Tujuan kajian ini adalah untuk menyiasat proses penyembuhan luka in vitro dengan menggabungkan ekstrak akueus Manihot esculenta dengan terapeutik ultrabunyi. Pertama, pembenihan sel HSF1184 yang dioptimumkan dalam enam plat dan kemudian diikuti oleh percubaan gores. Goresan yang dibuat telah dirawat dengan semua rawatan pemulihan (Manihot esculenta ekstrak akueus sahaja; askorbik asid + terapeutik ultrabunyi; Manihot esculenta ekstrak akueus + askorbik asid; Manihot esculenta ekstrak akueus + terapeutik ultrabunyi dan juga gabungan ketiga bahan). Penutupan luka telah diperhatikan dan dianalisis pada selang waktu $0,2,4,6,8,10$ dan 24 jam dengan menggunakan perisian imej J. Kemudian, daya maju sel telah dianalisis dengan menggunakan uji MTT. Hasilnya menunjukkan bahawa dengan menggabungkan ekstrak akueus Manihot esculenta dengan dos khusus terapi ultrabunyi mempersembahkan kadar penutupan luka paling tinggi pada $96.10 \%$ dengan nombor sel pada $5.44 \times 10^{5}$ sel $/ \mathrm{mL}$ berbanding dengan rawatan pemulihan yang lain dalam kajian ini. Dapatan kajian ini menunjukkan bahawa Manihot esculenta ekstrak akueus $200 \mu \mathrm{g} / \mathrm{mL}$
\end{abstract}


dengan dos khusus terapeutik ultrabunyi $\left(3 \mathrm{MHz}, 300\right.$ mWatt $/ \mathrm{cm}^{2}, 50 \%$ dalam 5 minit) untuk mempercepat proses penyembuhan luka sel dalam in vitro.

Kata kunci: Penyembuhan luka, Manihot esculenta, Terapeutik ultrabunyi, Uji Gores, Uji MTT

(C) 2019 Penerbit UTM Press. All rights reserved

\subsection{INTRODUCTION}

Chronic wound is a wound which does not heal in an orderly phase of wound healing (haemostasis, inflammatory, proliferative and remodelling phase). While venous leg ulcers, diabetic foot ulcers, and pressure ulcers are some of the examples of chronic wound disease [1,2]. Currently, compression therapy, antibiotic, antibacterial, irrigation and debridement are commonly used to enhance the healing of these chronic wounds [3, 4]. Compression therapy increased blood flow towards the heart and reduce venous reflux to heal venous leg ulcers [5]. According to Tan et al. (2007), therapeutic ultrasound at the lower frequencies had improved in wound healing process for venous ulcers when compared to compression therapy treatment [6]. Therapeutic ultrasound has advantages at the first and second phases (inflammatory and proliferative phase) of wound healing process for diabetic foot ulcers; it prevented patients with diabetes to undergo amputation [7].

Therapeutic ultrasound is secure and a beneficial treatment to combine with the biochemical therapy such as plant extract in order to heal the chronic wounds [8]. Nevertheless, to our best of knowledge the combination of therapeutic ultrasound with the plant extract has not been proven scientifically in accelerating the wound healing in in vitro. The medicinal plant that traditionally used for wound healing are such as Aloe vera, Carica papaya, Curcuma longa, Moringa oleifera Lam and Zingiber officinale [9, 10]. Cassava (Manihot esculenta) leaves is believed by developing country such as Indonesia to be used for the wound healing process [11, 12]. Manihot esculenta have many beneficial from roots, stem to leaves and its leaves consist of protein, vitamin C (ascorbic acid), flavonoid, saponin, tannin and triterpenoid which is higher than other vegetables [11, 12 , 13]. Furthermore, ascorbic acid has role in accelerating the wound healing process [14]. Concentration $0.06 \mathrm{mM}$ of ascorbic acid was studied to stimulate proliferation of human skin fibroblast cells, provoke collagen synthesis (as cofactor for prolyl hydroxylase) and its deposition in the extracellular matrix [15]. Thus, it used for positive control in this research.

According to Meilawaty (2013), Manihot esculenta leaves extract have a role in accelerating wound healing by reducing the inflammation [16]. It has potential in decreasing the neutrophil cells during the wound healing process in in vivo [12]. In related to that, therapeutic ultrasound play a role in first phase of wound healing process (inflammatory phase) in the degranulation of mast cells [2]. In our study, Manihot esculenta aqueous extract and therapeutic ultrasound were introduced to identify their capabilities and potential to accelerate the wound healing process rather than single treatment alone.

\subsection{METHODOLOGY}

\subsection{Materials}

DMEM (Dulbecco's Modified Eagle's Medium) were purchased from the Interscience Company (Shah Alam, Selangor Darul Ehsan, Malaysia). Trypsin, TrypsinEDTA and Fetal Bovine Serum (FBS) standard were acquired from Biowest Company (Puchong, Selangor, Malaysia). Penicillin-Streptomycin (Pen/Strep), Ascorbic acid, MTT (Thiazolyl Blue Tetrazolium Bromide) powder and Trypan blue solution were purchased from SigmaAldrich Group (Subang Jaya, Selangor, Malaysia).

\subsection{Preparation of Manihot esculenta Aqueous Extract}

The leaves of Manihot esculenta were plucked, washed, and cut into pieces before dried under shade condition at room temperature for 6 to 7 days [11]. Direct exposure of sunlight would cause destruction of the bioactive compound contained in the leaves extract [17]. The dried leaves of Manihot esculenta were then ground into powder form [18] and soaked into deionized water at room temperature for $24 \mathrm{~h}$ in ratio of 1:10 (w/v) [19-22]. After that, it was filtered and sent for evaporation using the EYELA N-1000 rotary evaporator (Tokyo Riakakikai Co., Tokyo) [23]. The gummy extract obtained was freezed dried (Beta 2-4 LD plus LT, Martin Chris, Germany) in order to remove the remaining solvent. Manihot esculenta aqueous extract was then kept at $4^{\circ} \mathrm{C}$ prior to use [24].

\subsection{Optimizing Cells Seeding Density}

Human Skin Fibroblast (HSF) 1184 cells were seeded in six-well plate containing DMEM complete medium with 
a range $1 \times 10^{5}$ cells $/ \mathrm{mL}$ to $6 \times 10^{5}$ cells $/ \mathrm{mL}$ densities in order to ensure the optimum cell seeding density [25]. Their confluency (80-90\%) was observed under the inverted microscope (Nikon Eclipse Ti-S microscope with Q-imaging Retiga $2000 \mathrm{R}$ camera) for $24 \mathrm{~h}$ before it will be further used in this study.

\subsection{MTT Cytotoxicity Assay of Manihot esculenta}

Manihot esculenta aqueous extract with different concentrations ranging from $1.95 \mu \mathrm{g} / \mathrm{mL}$ to $500 \mu \mathrm{g} / \mathrm{mL}$ was prepared. It was tested for in vitro cytotoxicity, using HSF 1184 cell lines. $20 \mu \mathrm{L}$ of MTT solution was added in each well after $72 \mathrm{~h}$ [26]. After that, the solution in each well was discarded and MTT dissolving buffer was added into each well. The absorbance was read at $577 \mathrm{~nm}$ by using Promega GloMax Multi Detection System (Interscience Company, Shah Alam, Selangor Darul Ehsan, Malaysia).

\subsection{Wound Scratch Assay}

The scratch assay is known as an appropriate and economical tool to observe cell movement in in vitro [27]. By using a fine tip marker, a straight line at the bottom of six well plates was made as the guidance line for scratch assay. Then, fibroblast cells were seeded into a six-well plate and allowed to attach, spread, and grow to confluence in six-well plates [28]. After forming a confluent monolayer in $24 \mathrm{~h}$, a straight line was created by using a sterile yellow pipette tip across each the well of plates [29]. Wound scratch assay was done softly and at a low speed at the centre of well plates in straight line in one way [27].

\subsubsection{Manihot esculenta Aqueous Extract Treatment}

The old medium in each well was sucked out and washed gently with the PBS twice to remove the detached cells [30]. Then, the fresh medium and Manihot esculenta aqueous extract $200 \mu \mathrm{g} / \mathrm{mL}$ was added into the treatment groups well while the control group was kept with the same condition as the treatment groups without any Manihot esculenta aqueous extract treatment. Both groups were run in triplicates.

\subsubsection{Therapeutic Ultrasound Exposure}

The Sonopuls 492 (JH Enraf-Nonius, Subang Jaya, Selangor Darul Ehsan, Malaysia) was used in this study. The exposure of therapeutic ultrasound was set up at 3 $\mathrm{MHz}$, intensity $0.3 \mathrm{Watt} / \mathrm{cm} 2$ and pulse $50 \%$ for $5 \mathrm{~min}$ [31]. Frequency of $3 \mathrm{MHz}$ was used for superficial lesions at depths less than $2 \mathrm{~cm}$ wherein fibroblast cells located [32, 33, 34]. The six-well plate with fibroblast cells in DMEM medium was located on top of ultrasound transducer.

\subsubsection{Ascorbic Acid Treatment}

Treatment with the ascorbic acid (positive control drug) was done. Ascorbic acid with $0.4 \mathrm{mg}$ dissolved in $5 \mathrm{~mL}$ sterile water. The deionized water was sterilized through a $0.2 \mu \mathrm{m}$ nylon filter Whatmann [35]. Subsequently, ascorbic acid solution was diluted to the concentration of $10 \mu \mathrm{g} / \mathrm{mL}$. Concentration $0.06 \mathrm{mM}$ of ascorbic acid was reported to stimulate proliferation of human skin fibroblast cells [36]. Lastly, ascorbic acid solution was added to each treatment well.

\subsection{Image Analysis}

The scratch images were taken using the camera (Qimaging Retiga 2000R camera, Canada) attached to the inverted microscope (Nikon Eclipse Ti-S microscope, USA) after the cells were treated with the remedial treatments (Manihot esculenta aqueous extract alone; ascorbic acid+ therapeutic ultrasound; Manihot esculenta aqueous extract+ ascorbic acid; Manihot esculenta aqueous extract+ therapeutic ultrasound; and also the combination of these three materials) at the specific time interval $(0,2,4,6,8,10$ and $24 \mathrm{~h})$. The images were then analysed by using Image $\mathrm{J}$ software [37].

\subsection{MTT Assay}

The (3-(4,5-dimethylthiazol-2-yl) -2, 5-diphenyl tetrazolium bromide) (MTT) assay is a compatible and low-cost method for determining living cell number by forming dissolved blue formazan as mitochondrial enzyme activities in in vitro experiments [38].

A standard curve experiment was done to define the total cell number for MTT scratch assay by using seeding density of $1 \times 10^{5}$ to $6 \times 10^{5}$ cells $/ \mathrm{mL}$. According to Suzuki et al. (2011), standard curve is a tool used as quantitative research purposes by plotting data to build a graph [39]. The absorbance obtained from the MTT reading is the value for cell contents in well so that standard curve was prepared to determine the total cell number of HSF 1184 cells from the MTT reading [40]. Firstly, the fibroblast cells were seeded onto six-well plates and cultured for $24 \mathrm{~h}$. Afterwards, the absorbance of the MTT assay experiment was plotted to obtain a standard curve for each seeding density of fibroblast cells.

The six-well plates with the remedial treatments were incubated for $24 \mathrm{~h}$. Later, MTT assay was done by adding $300 \mu \mathrm{L}$ of MTT reagent into each control and treatment wells. The plate was wrapped well with aluminium foil and stayed in CO2 incubator (NuAire IR Autoflow CO2 Water-Jacketed Incubator, USA) at $37^{\circ} \mathrm{C}$ for $4 \mathrm{~h}$. The old medium was sucked out from each well and $3 \mathrm{~mL}$ of MTT dissolving buffer was added into each well. The absorbance of the purple colour solution was read at $577 \mathrm{~nm}$ using Promega GloMax Multi Detection System. 


\subsection{Statistical Analysis}

The normality of the data was determined using the Shapiro-Wilk test. The independent t-test was used to analyse the normal data while non-normal data was analysed by the Mann-Whitney test. Analysis was used to determine the significant differences between groups. The number of asterisks represented the significance level of correlation among both groups which were ${ }^{*} p<0.05,{ }^{* *} p<0.01,{ }^{* * *} p<0.001$ [41].

\subsection{RESULTS AND DISCUSSION}

\subsection{Optimization of Seeding Cells Density on Six-Well Plate}

HSF 1184 cells were seeded in six-well plate with a specific range of seeding number $\left(1 \times 10^{5}\right.$ to $6 \times 10^{5}$ $\mathrm{cells} / \mathrm{mL}$ ). The result showed that the cell seeding number of $4 \times 10^{5}$ cells $/ \mathrm{mL}$ in six-well plate for HSF cell lines was the most suitable for the experiments due to $80 \%$ of cell confluency in $24 \mathrm{~h}$.

\subsection{MTT Cytotoxicity Assay of Manihot esculenta Aqueous Extract}

Based on Figure 1, it can be calculated that IC50 value was $320 \mu \mathrm{g} / \mathrm{mL}$. According to U.S National Cancer Institute plant screening program, in the preliminary experiment, a crude extract is considered to have high cytotoxic activity if the IC50 is $20 \mu \mathrm{g} / \mathrm{mL}$ or less [42]. Hence, the Manihot esculenta aqueous extract was found to have a weak cytotoxic effect on HSF 1184 cells tested which IC50 was 201-500 $\mu \mathrm{g} / \mathrm{ml}$ [43].

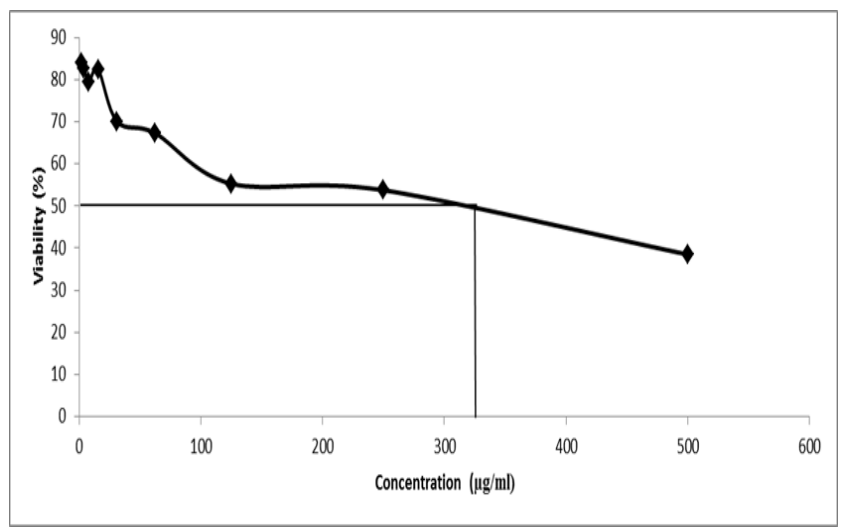

Figure 1 Graph of cell viability from different concentration of Manihot esculenta aqueous extract on the HSF cells

Based on the IC50 $(320 \mu \mathrm{g} / \mathrm{mL})$ value from the MTT assay, the experiment was continued with the scratch assay. The scratch assay was done with three different concentrations; $100 \mu \mathrm{g} / \mathrm{mL}, 200 \mu \mathrm{g} / \mathrm{mL}$, and $300 \mu \mathrm{g} / \mathrm{mL}$. These concentrations were less than IC50 value which was not toxic to the cells [44].
3.3 Scratch Assay Analysis of Manihot esculenta Aqueous Extract Treatment

Based on the scratch assay analysis, all of the concentration of Manihot esculenta aqueous extract showed a wound closure in this study. However, at the concentration of $200 \mu \mathrm{g} / \mathrm{mL}$ it shows the highest wound closure than concentration of $100 \mu \mathrm{g} / \mathrm{mL}$ and 300 $\mu \mathrm{g} / \mathrm{mL}$ (Figure 2)

3.4 Scratch Assay Analysis of the Combining of Manihot esculenta Aqueous Extract, Therapeutic Ultrasound and Ascorbic Acid

Based on the graph (Figure 3), the treated HSF 1184 cells with Manihot esculenta (ME) aqueous extract 200 $\mu \mathrm{g} / \mathrm{mL}$ shows a significantly higher wound closure at time interval $4,6,8$, and $10 \mathrm{~h}\left({ }^{*} p<0.05,{ }^{* *} p<0.01\right)$. On the contrary, the treated HSF 1184 cells with Manihot esculenta aqueous extract $200 \mu \mathrm{g} / \mathrm{mL}$ and ascorbic acid (AA) $10 \mu \mathrm{g} / \mathrm{mL}$ shows a low progress of cell migrations with a significant value at intervals of 2,4 and $10 \mathrm{~h}\left({ }^{*} \mathrm{p}<0.05,{ }^{* *} \mathrm{p}<0.01\right)$.

The treated HSF 1184 cells with Manihot esculenta aqueous extract $200 \mu \mathrm{g} / \mathrm{mL}$ and therapeutic ultrasound (3 MHz, $300 \mathrm{mWatt} / \mathrm{cm} 2,50 \%$ in $5 \mathrm{~min}$ ) shows a high progress of cell migrations (Figure 3). From the graph, it shows that the combining of Manihot esculenta aqueous extract and therapeutic ultrasound (US) gives positive effects to cell migrations and displays a uniform pattern of cell migration.

The combining therapy among Manihot esculenta aqueous extract, ascorbic acid and therapeutic ultrasound gives positive effects, but still lower than Manihot esculenta aqueous extract coupled with therapeutic ultrasound. The result had revealed that the combination of these three materials had the rate of wound closure at $89.79 \%$ after $10 \mathrm{~h}$ while the combination of Manihot esculenta aqueous extract coupled with therapeutic ultrasound had a significantly higher rate of wound closure at $96.10 \%$ after $10 \mathrm{~h} 1^{* *} \mathrm{p}<$ $0.01)$.

The role of ascorbic acid in this experiment is as positive control. Concentration $0.06 \mathrm{mM}$ of ascorbic acid was studied to stimulate proliferation of human skin fibroblast cells, provoke collagen synthesis las cofactor for prolyl hydroxylase) and its deposition in the extracellular matrix [15]. However, it is also reported that ascorbic acid at markedly higher concentrations used in medium are lethal, which can inhibit cell proliferation as well as cell apoptosis [45]. This study shows that ascorbic acid alone gives positive effects, but still lower than Manihot esculenta aqueous extract coupled with therapeutic ultrasound. 


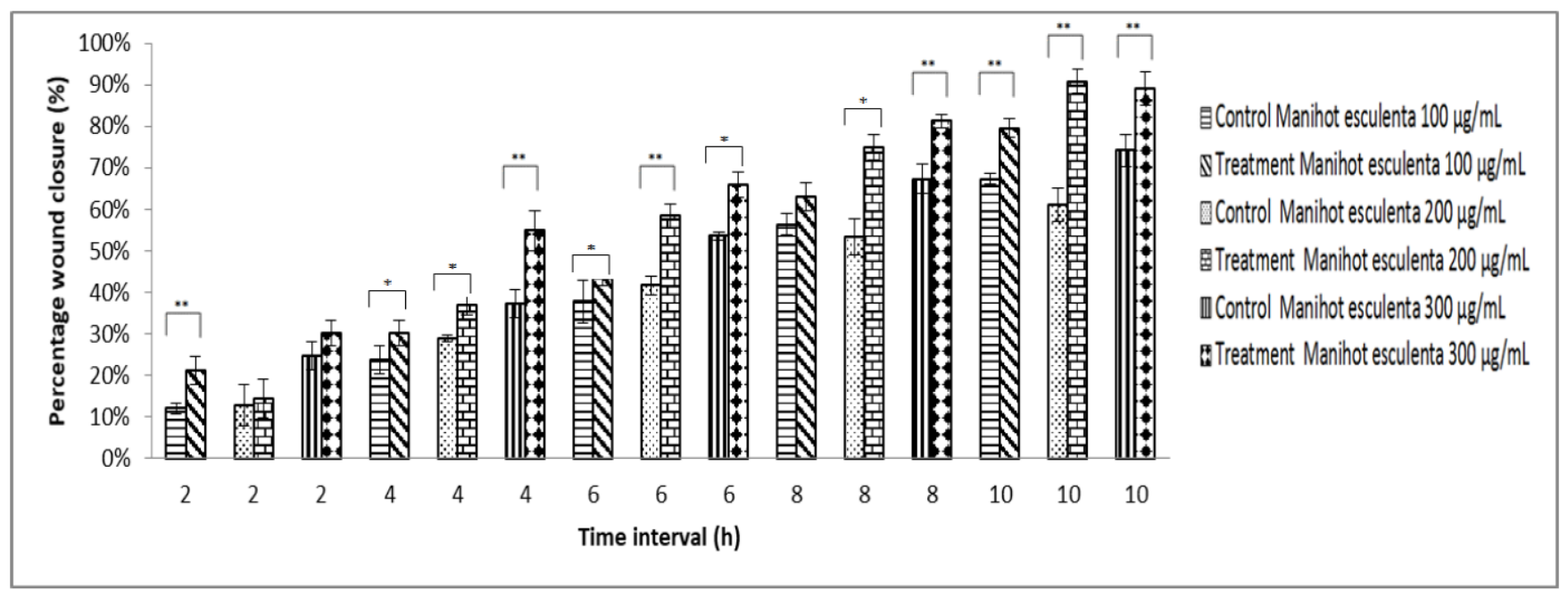

Figure 2 Percentage of wound closure after treated with the Manihot esculenta aqueous extract with a specific time interval $(0,2$ $4,6,8$ and 10 h). Significant $\left({ }^{*} p<0.05,{ }^{* *} p<0.01,{ }^{* * *} p<0.001\right)$ differences between the groups are indicated by asterisks

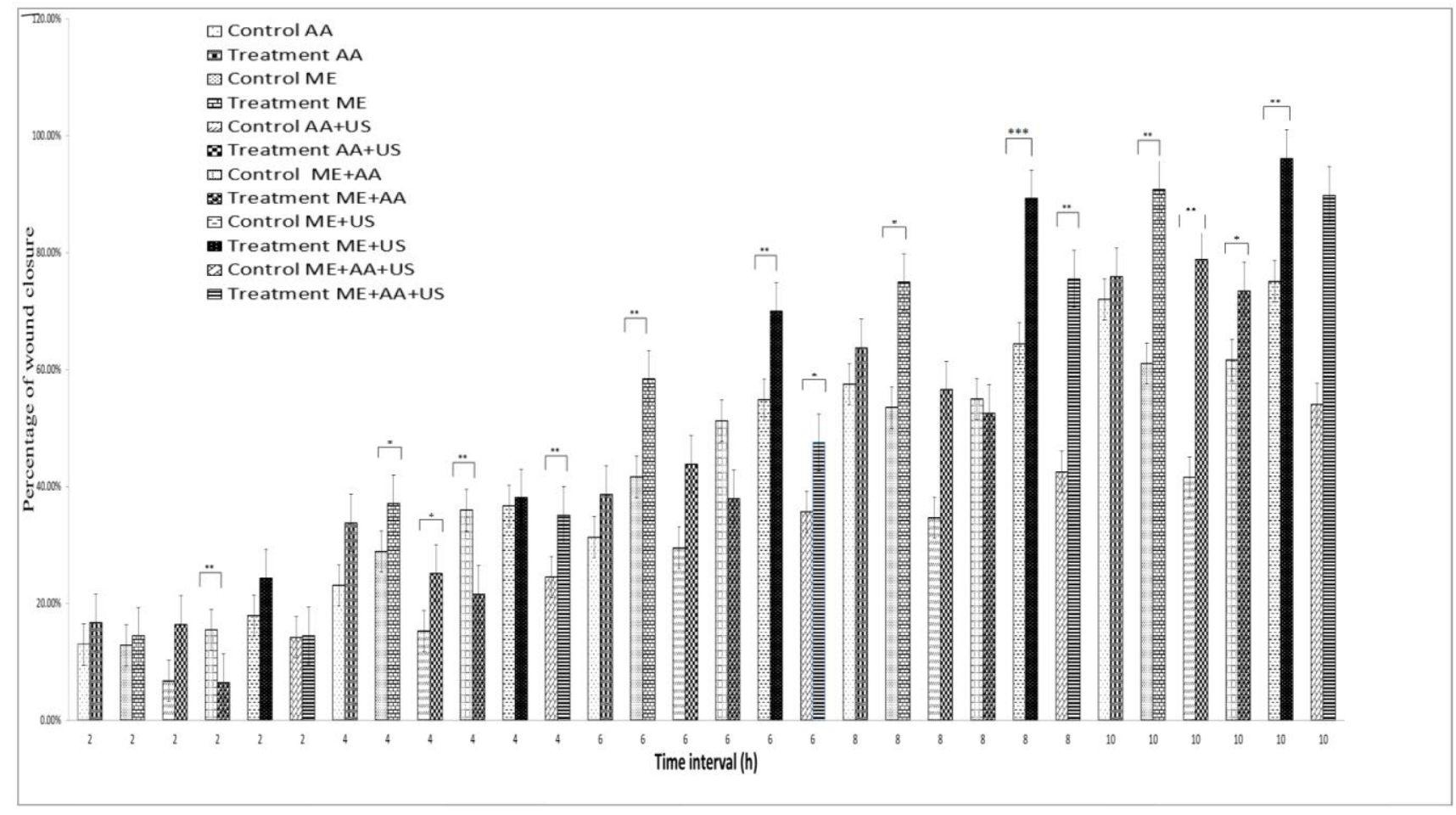

Figure 3 Percentage of wound closure after treated with five remedial treatments with a specific time interval $(0,4,6,8$ and $10 \mathrm{~h})$. Significant $\left({ }^{*} p<0.05,{ }^{* *} p<0.01,{ }^{* * *} p<0.001\right)$ differences between the groups are indicated by asterisks 
The cell viability (Figure 4) -shows that Manihot esculenta aqueous extract coupled with therapeutic ultrasounds $\left(3 \mathrm{MHz}, 0.3\right.$ Watt/ $\mathrm{cm}^{2}$ with $50 \%$ pulse mode in $5 \mathrm{~min}$ ) significantly increased the cell numbers $\left({ }^{*} p<0.05\right)$ when compared to the other combination therapy (Manihot esculenta aqueous extract alone; ascorbic acid+ therapeutic ultrasound; Manihot esculenta aqueous extract+ ascorbic acid; and the combination of these three materials). The combination of Manihot esculenta aqueous extract and therapeutic ultrasound enhance the cell numbers at $5.44 \times 10^{5}$ cells $/ \mathrm{mL}$, proved that the potential effect of Manihot esculenta aqueous extract combined with therapeutic ultrasounds with a specific dose.

The result presented here suggest that Manihot esculenta aqueous extract coupled with therapeutic ultrasound treatment had a good effect on scratch assay analysis and cell viability. Based on the graph (Figure 3), the treated HSF 1184 cells with Manihot esculenta aqueous extract $200 \mu \mathrm{g} / \mathrm{mL}$ and therapeutic ultrasound ( $3 \mathrm{MHz}, 300 \mathrm{mWatt} / \mathrm{cm}^{2}, 50 \%$ in $5 \mathrm{~min}$ ) had shown a significantly high progress of cell migrations at intervals of 4,6 and $10 \mathrm{~h}\left({ }^{* *} \mathrm{p}<0.01\right.$, $\left.{ }^{* * *} p<0.001\right)$. This finding was supported by previous study that reported that Manihot esculenta extract had a role in inflammatory phase of wound healing [16].

In related to that, therapeutic ultrasound activates inflammatory cells that play a role in the production of chemical mediators, resulting in the activation of fibroblasts proliferation [46, 47].

Due to the potential of phytochemical content in Manihot esculenta leaves, Manihot esculenta extract has capability to accelerate wound healing process [7]. Saponin and flavonoid has anti-inflammation activity and tannin and triterpenoid are known to have antioxidant activity $[48,49]$. Vitamin C (ascorbic acid) in Manihot esculenta leaf helps synthesizes collagen of the proliferation process and flavonoid helps to protect the oxidation of ascorbic acid, thus improving the process of collagen synthesis $[50,51]$.

The cell viability of the Manihot esculenta aqueous extract $200 \mu \mathrm{g} / \mathrm{mL}$ (Figure 4) had appreciable effect to stimulates cell significantly $\left({ }^{*} p<0.05\right)$ with the cell numbers at $5.01 \times 10^{5}$ cells $/ \mathrm{mL}$. According to Nisa et al. (2013), the extract of Manihot esculenta had potential to improve the quality of connective and epithelial tissue in the wound healing process in in vivo [11]. Furthermore, the fibroblast is one of the connective tissue cells which has role in wound healing process and had been used in this study [51].

Therapeutic ultrasound is secure and beneficial treatment to combine with biochemical therapy in order to heal the wounds [8]. Furthermore, therapeutic ultrasounds with a dose of $3 \mathrm{MHz}, 0.3$ Watt/cm2 with $50 \%$ pulse mode had demonstrated to have positive effect on HSF 1184 fibroblast cell lineage after 5 minutes of exposure [31]. Based on Figure 4, the combination of Manihot esculenta aqueous extract and therapeutic ultrasound enhance the cell numbers at $5.44 \times 10^{5}$ cells $/ \mathrm{mL}$, proved that the potential effect of Manihot esculenta aqueous extract combined with therapeutic ultrasounds with a specific dose. In comparison with Mahdzir's work, these combining therapies have better effect than the therapeutic ultrasound alone.

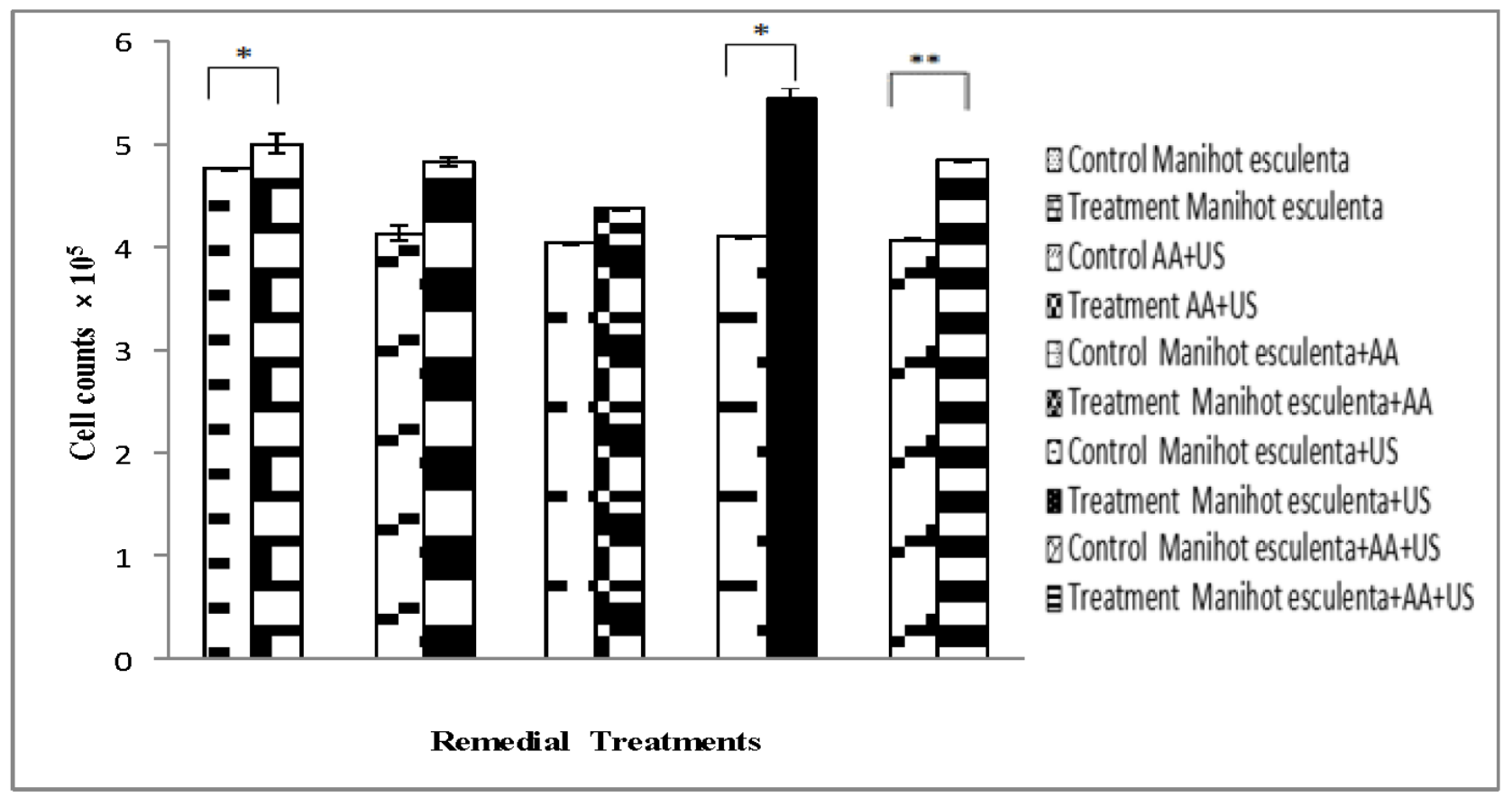

Figure 4 Total cell numbers of HSF 1184 cells from the scratch assay using the MTT assay of five remedial treatments. Significant $\left({ }^{*} p<\right.$ $0.05,{ }^{* *} p<0.01,{ }^{* *} p<0.001$ ) differences between the groups are indicated by asterisks 


\subsection{CONCLUSION}

This study shown that Manihot esculenta aqueous extract $200 \mu \mathrm{g} / \mathrm{mL}$ and the therapeutic ultrasound specific dose ( $3 \mathrm{MHz}, 300 \mathrm{mWatt} / \mathrm{cm}^{2}, 50 \%$ in $5 \mathrm{~min}$ ) have the potential in accelerating wound healing process of cells in in vitro. Furthermore, this research has limitation on the method of wound healing; the scratch assay method can be replaced by gap closure method (using a biocompatible hydrogel chamber), so it will create a consistent circle shape. Hence, the result of image $J$ analysis will not leave a residue that could interfere with cell migration in 6well plates. On top of that, more in vivo studies of the Manihot esculenta aqueous extract and therapeutic ultrasound on intact tissue should be conducted to investigate the physiological effects of this combining therapy. Thus, it is recommended that Manihot esculenta aqueous extract and the therapeutic ultrasound specific dose can be tested in in vivo model.

\section{Acknowledgement}

The authors fully acknowledged Universiti Teknologi Malaysia for the facility which makes this important research viable and effective.

\section{References}

[1] Diegelmann, R. F, Evans, M. C. 2004. Wound Healing: An Overview of Acute, Fibrotic and Delayed Healing. Front Biosci. 1 (4): 283-289.

[2] Krishnasamy, M. 2006. Technology Review: Utrasound Assisted Wound Care. 1-11.

[3] Nicks, B. A., Ayello, E. A., Woo, K., Nitzki-George, D., Sibbald, R. G. 2010. Acute Wound Management: Revisiting the Approach to Assessment, Irrigation, and Closure Considerations. Int. J. Emerg. Med. 3(4): 399-407.

[4] Mustoe, T. A,, O'Shaughnessy, K., Kloeters, O. 2006. Chronic Wound Pathogenesis and Current Treatment Strategies: A Unifying Hypothesis. Plast. Reconstr. Surg. 117 (7 Suppl): 35S41S.

[5] Moffatt, C., \& Rabe, E. 2003. Understanding Compression Therapy. 1-17.

[6] Tan, J., Abisi, S., Smith, A., \& Burnand, K. G. 2007. A Painless Method of Ultrasonically Assisted Debridement of Chronic Leg Ulcers: A Pilot Study. European Journal of Vascular and Endovascular Surgery. 33: 234-238.

[7] Ennis, W. J. et al. 2005. Ultrasound Therapy for Recalcitrant Diabetic Foot Ulcers: Results of a Randomized, Doubleblind, Controlled, Multicenter Study. Ostomy Wound Manage. 51 (8): 24-39.

[8] Kwiatkowska, B., Bennett, J., Akunna, J., Walker, G. M., Bremner, D. H. 2011. Stimulation of Bioprocesses by ultrasound. Biotechnol Adv. 29: 768-80.

[9] Muhammad, A. A., Aimi, N., Pauzi, S., Arulselvan, P., Abas, F., Fakurazi, S. 2013. In Vitro Wound Healing Potential and Identification of Bioactive Compounds from Moringa oleifera Lam. 1-10.

[10] Wadankar, G. D., Malode, S. N., Sarambekar, S. L. 2011. Traditionally Used Medicinal Plants for Wound Healing in the Washim District, Maharashtra (India). International Journal of PharmTech Research. 3(4): 2080-2084.
[11] Nisa, V. M., Meilawaty, Z., Astuti, P. 2013. The Effect of Cassava Leaves Extract (Manihot esculenta) on Gingival Wound Healing Rats. Artik. IIm. Has. 1-7.

[12] Nurdiana, A. R. 2013. Uji Ekstrak Daun Singkong (Manihot esculenta) Terhadap Jumlah Neutrofil pada Proses Penyembuhan Luka Tikus ( Rattus norvegiccus ). 1-58.

[13] Restrepo, S., Duque, M. C., Verdier, V. 2000. Characterization of Pathotypes among Isolates of Xanthomonas axonopodis pv. manihotis in Colombia. Plant Pathol. 49:680-687.

[14] Choi, H.-I., Park, J.-I., Kim, H.-J., Kim, D.-W., \& Kim, S.-S. 2009. A Novel L-ascorbic Acid and Peptide Conjugate with Increased Stability and Collagen Biosynthesis. BMB Reports. 42(11): 743-746.

[15] Schmidt, R. J., Chung, L. Y., Andrews, A. M., Turner, T. D. 1993. Toxicity of L-ascorbic Acid to L929 Fibroblast Cultures: Relevance to biocompatibility Testing of Materials for Use in Wound Management. J. Biomed. Mater. Res. 27: 521530.

[16] Meilawaty, Z. 2013. Potensi Ekstrak Daun Singkong (Manihot Utilissima) dalam Memodulasi Ekspresi COX-2 Pada Monosit Yang Dipapar LPS. 1-16.

[17] Anibijuwon, I. I., Udeze, A. O. 2009. Antimicrobial Activity of Carica Papaya (Pawpaw Leaf) on Some Pathogenic Organisms of Clinical Origin from South-Western Nigeria. Ethnobotanical Leaflets. 13: 850-64.

[18] Al-Rofaai, A., Rahman, W. A., Sulaiman, S. F., \& Yahaya, Z. S. 2012. Veterinary Parasitology in vitro Ovicidal and Larvicidal Activity of Methanolic Leaf Extract of Manihot esculenta (cassava) on Susceptible and Resistant Strains of trichostrongylus colu-briformis. Veterinary Parasitology. 190(1-2): 127-135.

[19] Al-Ansari A-Mehdi, S., Abdulkareem, M. a. 2014. Some Plant Extracts Retarde Nitrification in Soil. Acta Agric. Slov. 103(1): 5-13.

[20] Chew, K., Aida, W. 2011. Effect of Ethanol Concentration, Extraction Time and Extraction Temperature on the Recovery of Phenolic Compounds and Antioxidant Capacity of Centella Asiatica Ex-tracts. Int. Food Res. J. 18: 571-578.

[21] Parekh, J., Jadeja, D., Chanda, S. 2005. Efficacy of Aqueous and Methanol Extracts of Some Medicinal Plants for Potential Antibacterial Activity. Turk J Biol. 29: 203-210.

[22] James, O., Friday, E. T. 2010. Phytochemical Composition, Bioactivity and Wound Healing Potential of Euphorbia heterophylla (Euphorbiaceae) Leaf Extract. Int. J. Pharm. Biomed. Res. 1 (1): 54-63.

[23] Marie-magdeleine, C., Udino, L., Philibert, L., Bocage, B. Ar-chimede, H. 2010. Veterinary Parasitology In vitro Effects of Cassava (Manihot esculenta) Leaf Extracts on Four Development Stages of Haemonchus contortus. Vet. Parasitol. 173(1-2): 85-92.

[24] Yusuf, U. F., Okechukwu, P. N. 2013. Anti-inflammatory, Analgesic and Anti-pyretic Activity of Cassava Leaves Extract. Asian J Pharm Clin Res. 6(4): 89-92.

[25] Zhou, H., Weir, M. D., Ph, D., XU, H. H. K. 2011. Effect of Cell Seeding Density on Proliferation and Osteodifferentiation of Umbilical Cord Stem Cells on Calcium Phosphate Cement-Fiber Scaffold. Tissue Eng. 17(21-22): 2603-2613.

[26] Rahmat, A., Kumar, V., Fong, L. M., Endrini, S. 2003. Determination of Total Antioxidant Activity in Three Types of Local Vegetables Shoots and the Cytotoxic Effect of Their Ethanolic Extracts against Different Cancer Cell Lines. Asia Pac J Clin Nutr. 12(3): 308-311.

[27] Liang, C-C., Park, A. Y., Guan, J-L. 2007. In Vitro Scratch Assay: A Convenient and Inexpensive Method for Analysis of Cell Migration In Vitro. Nat. Protoc. 2(2): 329-333.

[28] Hulkower, K. I., Herber, R. L. 2011. Cell Migration and Invasion Assays as Tools for Drug Discovery. Pharmaceutics. 3(1): 107-124.

[29] Yarrow, J. C., Perlman, Z. E., Westwood, N. J., Mitchison, T. J. 2004. A High-Throughput Cell Migration Assay using Scratch Wound Healing, A Comparison of Image-based Readout Methods. BMC Biotechnol. 4(21): 1-9. 
[30] Freshney, R. I. 2005. Culture of Animal Cells: A Manual of Basic Technique. Fifth Edition. New Jersey: John Wiley \& Sons, Inc.

[31] Mahdzir, N. S. B. 2015. Therapeutic Ultrasound as an Alternative Treatment for Wound Healing in In Vitro. 1-91.

[32] Speed, C. 2001. Therapeutic Ultrasound in Soft Tissue Lesions. Rheumatology (Oxford). 40(12): 1331-6.

[33] Sorrell, J. M., Caplan, A. I. 2004. Fibroblast Heterogeneity: More than Skin Deep. J. Cell Sci. 17(5): 667-675.

[34] Varkey, M., Ding, J., Tredget, E. E. 2015. Advances in Skin Substi-tutes-Potential of Tissue Engineered Skin for Facilitating Anti-Fibrotic Healing. J. Funct. Biomater. 6(3): 547-563.

[35] Otero, M., Favero, M., Dragomir, C. et al. 2014. Human Chondrocyte Cultures as Models of Cartilage-Spesific Gene Regulation. Methods Mol Med. 107(4): 69-95.

[36] Matsubayashi, Y., Razzell, W., Martin, P. 2011. "White Wave" Analysis of Epithelial Scratch Wound Healing Reveals How Cells Mobilise Back from the Leading Edge in a Myosin-IIDependent Fashion. J. Cell Sci. 124(7): 1017-1021.

[37] Sylvester, V. W. 2011. Optimization of the Tetrazolium Dye (MTT) Colorimetric Assay for Cellular Growth and Viability. Methods Mol Biol. 716: 157-68.

[38] Suzuki, O., Koura, M., Noguchi, Y., Uchio-yamada, K., \& Matsuda, J. 2011. Use of Sample Mixtures for Standard Curve Creation in Quantitative Western Blots. Experimental Animals. 60(2): 193-196.

[39] Brescia, P., SC, M., Banks, P., Ph, D., \& Instruments, B. 2009. Quantifying Cytotoxicity of Thiostrepton on Mesothelioma Cells using MTT Assay and the Epoch TM Microplate Spectrophotometer.

[40] Pallant, J. 2010. SPSS Survival Manual: A Step by Step Guide to Data Analysis using SPSS. 3rd ed) Maidenhead: Open University Press/McGraw-Hill.

[41] Malek, S. N. A., Phang, C. W., Ibrahim, H., Norhanom, A. W., \& Sim, K. S. 2011. Phytochemical and Cytotoxic Investigations of Alpinia Mutica Rhizomes. Molecules. 16(1): 583-589.
[42] Sajjadi, S. E., Ghanadian, M., Haghighi, M., \& Mouhebat, L. 2015. Cytotoxic Effect of Cousinia Verbascifolia Bunge against OVCAR-3 and HT-29 Cancer Cells. Journal of HerbMed Pharmacology. 4(1): 15-19.

[43] Al-Qubaisi, M., Rozita, R., Yeap, S.-K., Omar, A.-R., Ali, A.-M., \& Alitheen, N. B. 2011. Selective Cytotoxicity of Goniothalamin against Hepatoblastoma HepG2 Cells. Molecules. 16(12): 2944-2959.

[44] Franco de Oliveira, R., Pires Oliveira, D., Soares, C. P. 2011. Effect of Low-intensity Pulsed Ultrasound on 1929 Fibroblasts. Arch. Med. Sci. 7(2): 224-229.

[45] K.-M. Choi et al., 2008. Effect of Ascorbic Acid on Bone Marrow-derived Mesenchymal Stem Cell Proliferation and Differentiation. J. Biosci. Bioeng. 105(6): 586-594.

[46] Unger, P. G. 2008. Low-frequency, Noncontact, Nonthermal Ultra-sound Therapy: A Review of the Literature. Ostomy Wound Manag. 54(1): 57-60.

[47] Aggarwal, B. B., Prasad, S., Reuter, S., Kannappan, R., Vivek, R. 2011. Identification of Novel Anti-inflammatory Agents from Ayurvedic Medicine for Prevention of Chronic Diseas-es: Reverse Pharmacology and Bedside to Bench Approach. Curr Drug Targets. 12(11): 713-794.

[48] Alajmi, M. F., Alam, P. 2014. Anti-inflammatory Activity and Qualitative Analysis of Different Extracts of Maytenus obscura (A. Rich.) Cuf. by High Performance Thin Layer Chromatography Method. Asian Pac. J. Trop. Biomed. 4(2): 152-7.

[49] Ganceviciene, R., Liakou, Al., Theodoridis, A., Makrantonaki, E., Zouboulis, C. C. 2012. Skin Anti-aging Strategies. Dermato-Endocrinology V. 4(3): 308-319.

[50] Schagen, S. K., Zampeli, V., Makrantonaki, E., Zouboulis, C. C. 2012. Discovering the Link Between Nutrition and Skin Aging. Dermatoendocrinol. 4(3): 298-307.

[51] Olczyk, P., Mencner, Ł., Komosinska-Vassev, K. 2014. The Role of the Extracellular Matrix Components in Cutaneous Wound Healing. Biomed Res. Int. 1-8. 